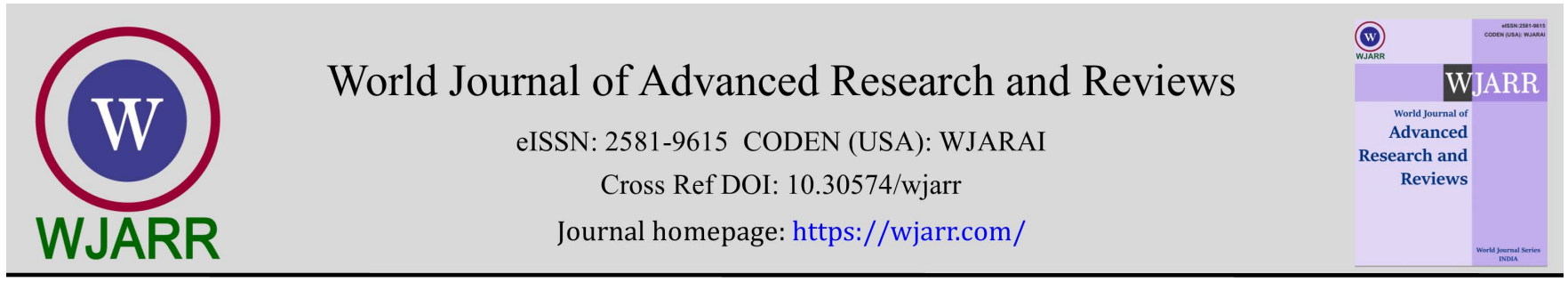

(RESEARCH ARTiClE)

Check for updates

\title{
The effect of inflation on economic growth in Ghana, 1995-2019: Post democratic analysis
}

\author{
Yenube Clement Kunkuaboor ${ }^{1,}{ }^{*}$, Moisob Adamu ${ }^{2}$, Miilon Sommik-Duut ${ }^{3}$ and Fatawu Abdul-Seidu 4 \\ ${ }^{1}$ PSS Ghana Creative Agency, Research and Design, Kumasi, Ghana. Phone (+233 245537425$)$. \\ 2 Moisob Adamu, Business School, Ghana Institute of Management and Public Administration (GIMPA), Ghana. \\ ${ }^{3}$ Miilon Sommik-Duut, National Ambulance Service (NAS), Kumasi, Ghana. \\ ${ }^{4}$ Fatawu Abdul Seidu, Ghana Water Company, Operation, Brekum, Ghana.
}

World Journal of Advanced Research and Reviews, 2021, 12(03), 230-242

Publication history: Received on 26 October 2021; revised on 11 December 2021; accepted on 13 December 2021

Article DOI: https://doi.org/10.30574/wjarr.2021.12.3.0660

\begin{abstract}
Background: One of the fundamental goals of macroeconomic policy in many nations, both developed and developing, is to foster economic development while keeping inflation low. There has been a debate as to whether inflation impacts negatively on economic growth or rather promotes economic growth. The study is motivated by this controversy and used time-series data from 1995 to 2019 in Ghana to examine the relationship between inflation and economic growth, establish the long-run effect and also test whether there exists a causal effect between inflation and economic growth.

Method: The review utilized Ordinary Least Square (OLS) regression examination to inspect the impact of inflation on economic growth and while long run co-integration relationship was additionally decide utilizing Fully Modified (FMOLS) regression analysis. Granger causality was investigated to see if there is a causal impact among inflation and economic growth. Model diagnoses were performed to discover the strength of the discoveries where autocorrelation, multicollinearity, normality test and heteroscedasticity were tested.
\end{abstract}

Results: The review uncovered that, inflation has a negative measurably irrelevant impact on economic growth at $5 \%$ basic level. The concentrate likewise uncovered that there was co-integration relationship between inflation and economic growth during the time of viable 1995-2019. There was no causal impact among inflation and economic growth, in this way neither inflation nor economic growth Granger-Causes the other. The study suggest that inflation targeting ought to be the best financial approach measure for economic growth by keeping up with the rate at $8+/-2 \%$.

Keywords: Inflation; Economic; GDP; Unit root; Co-integration; Augmented Dickey-Full (ADF); FM-OLS; Causality

\section{Introduction}

The sustainability of economic growth and economic development is pivotal in macroeconomic decisions and policy initiations of the most country [10]. Indeed, this perception does not go without drawing inflation into the picture as an essential ingredient in the fight to grow and sustain the economy by Sattarov. A country's improvement in the level of goods and service as production is a concern is classified as economic growth. Economic growth can be explained as Gross Domestic Product (GDP) which is equal to the sum of personal expenditure, plus domestic investment, Government expenditure, net exports of goods and services within an economy [3]. The mixed results mostly found in the literature is because the researchers do not come into agreement that inflation economic growth relationship is due to countries specific features [4].

\footnotetext{
* Corresponding author: Yenube Clement Kunkuaboor

PSS Ghana Creative Agency, Research and Design, Kumasi, Ghana.

Copyright $(2021$ Author(s) retain the copyright of this article. This article is published under the terms of the Creative Commons Attribution Liscense 4.0.
} 
According to [1] studied the effect of inflation on economic growth in the long run it was found out that inflation has a negative effect on economic growth of Ghana. A long-term co-integration was established using a quarterly data from 1986:Q1 to 2012:Q4 in Ghana, it was found out that there was a stable existence of long-run relationship between inflation and economic growth which was negative [1] GDP in nominal terms is used as a product to reproduce real GDP and the rate of interest which forms part of macroeconomic factors which is not stable and have a link with inflation [2]. Widely, it is agreed that low levels of the persistent and appreciable rise in the general price level of goods and services in an economy unaccompanied by food production supports the concept of economic growth. It is still being contested about the precise link that exist between inflation and economic growth. What however remains questionable is the nature of the correlation between these two series that have ignited academic debate in the global learning space [8]. This has led to the spring up of two schools of thought that have engaged the academia with their differing findings and theories on the association that does exist amid inflation and economic progress and how this established relationship impacts economic growth [7]. For instance, the view of the structuralists lends credence to inflation as being necessary if the economy should grow, whilst the monetarists believe that inflation is as evil as destruction for an economy to progress, [7].

In the 1960s, the general price level and progress of an economic models highlighted some set of instruments that when the inflation rate is higher it makes capital more attractive to clamp more money. This led to higher capital intensive, and the evolution period to greater economic progress [18]. Though, around 1970s, countries which were experiencing high rates of inflation, then economic growth began to decline (www.khanacademy.org). In the military and civilian rule, Ghana recorded one of the highest inflation rates due to overabundance and misapplications of finance in the monetary segment and the real economy and overall mismanagement which put pressure on domestic prices, recording Ghana's highest inflation rate of $123 \%$ in 1983 . This caused the manifestation of the several opinions that inflation is negatively impacted on the growth of a countries economy, as viewed by others that it has positively impacted on the growth of an economy [5]. According to [19], inflation periods and time trends are associated to hinder economic growth either positive or negative.

The Bank of Ghana's primary objective of monetarist policy is to sustain price stability and creating a conducive environment for economic growth. If the central Bank con consciously maintains its benchmark of $8 \pm 2 \%$ the economy is expected to grow at its full level without any unnecessary inflation pressures. According to the Monetary Policy Committee of the Bank of Ghana Nov 2020, have projected inflation to have generally been reviewed downwards in the term. The emergence of Covid-19 also caused the raise of inflation from the month of July to September, 2020 to increase and further came down to. In developed economies, inflation is expected to remain low, currency transactions and COVID-19 related supply-side constraints are expected to shape inflation dynamics in the frontier and emerging market in future form the data of Bank of Ghana, Nov 2020, stated in their media address. Economic growth is as a consequence of an increase of real GDP, is an increase that measures the national goods/products manufactured in fixed prices. The direct factor influence of Economic growth is human working capacity i.e increasing the number of people who are active and ready to work, investing in the populist, natural inheritance including (the surface and underground resources), as well as advancement or the level technology adopted.

Direct factors such as bodies like financial establishments, private administrations and others influenced Economic growth, the level of overall demand, investment and savings rate, how effective the financial system, the budget and fiscal policies, the level of the aggregate/total demand, rate of savings and investment rates, the effectiveness of the financial structure, budgetary and fiscal policies, movement of manual labour and funds, and government effectiveness. Some of the determinants of economic growth can also be pinpointed as a human capacity, the resources within the surface of the land, capital creation and technology. A world foremost economist mentions some time ago, that the most elementary element which happens in recent formations of economic growth models.

\subsection{Overview of Ghana's Economic Structure.}

Ghana's economy has been term as mixed system with comparatively modest size as measured by government outflows to GDP ratio ([3]. There is a need to maintain the mixed nature of the Ghana's economy with a modest strong state and bouncing private sector which was openly recognize way back in 1963 . The seven year development plan was introduce between 1963-1970, of the then Government CPP. The document was forwarded and also seen Green light in 1965. The Government size on average was $18.1 \%$ between the periods of 1965 to 2005. Under the CPP and Dr. Kwame Nkrumah who practice socialist economic system largely, the size of the government was just 25\%. The size of this government was much lower than the recorded $30 \%$ for United States and more than $50 \%$ for Sweden and other Scandinavian countries over the period of 30 years. In 1990s, Government size for Ghana was on average 19.8\% compared to government sizes of 50\% for Brunei, for Malaysia was 23.8\%, 28.6\% for Bahrain, 36\% for Oman, 19\% for Philippines and $17.6 \%$ for Singapore reported by [11]. 


\subsection{Evolution of Inflation in Ghana.}

The International Monetary Fund (IMF) says Ghana was not likely to go into an economic recession for the last two quarters the third and the fourth quarter due to the Coronavirus pandemic. Some development partners and the World Bank in the same period earlier warned Ghana the possibility of going into economic recession for coronavirus being the primary cause, these bodies made this statement in April 2020 when Ghana started recording coronavirus cases. Nevertheless, some of these predictions have emerged as Ghana's economy recorded a 1.1\% growth decline in the third quarter and $3.2 \%$ in the second quarter of 2020 comparing it to inflation rate for the two consecutive periods on average of $11.03 \%$ to $10.77 \%$ for the second and third quarter respectively (GSS, 2020). Inflation within that period gains some marginal improvement whiles economic growth was suffering for gain in the same period. This crisis leads Ghana into an economic recession as it experiences a two consecutive decline in growth rate, this type of economic crises actually happen in Ghana's economy since 1983 when the economy went into recession.

\subsection{The Link between Economic Growth and Inflation}

The association between inflation and economic growth was studied using thirty (30) years of data from 1960 to 1990 comprising of 100 countries by [12]. He made available other factors of economic growth he added inflation into the model where regression analysis of the equation was used. The analysis by Barro shows that when inflation goes up by $10 \%$ per year it result into a decline of Gross Domestic Product (GDP) of about $0.2 \%,-0.3 \%$ per year and a decline in the ratio of investment to GDP by $-0.4 \%,-0.6 \%$. Inflation was included in the model to find out its effect on real GDP by [27]. The study reveals that inflation has impacted negatively on economic growth rate.

The association between inflation and economic growth rate was analysed by [26] using data for developed and developing countries. They used the initial newly developed econometric model by [14] and [23] to study the threshold effect of inflation and economic growth. [26] used unbalanced panel data which contains 140 countries from a period of 1960 to 1998. They estimated the threshold level of $1 \%$ to $3 \%$ and $11 \%$ to $12 \%$ for developed and developing countries respectively. The study reveals that the threshold for developed countries was lower than the threshold level for developing countries. They also made mention that the inflation rate below the threshold is again to economic growth and inflation rate above were the threshold were negative and significant on economic growth.

In the case of Pakistan [29] also tress on the threshold level of inflation. [29] found out that threshold level of 9\% of inflation and when the threshold level is above the expected value poses a negative effect on economic growth and threshold level below the expected value rather improves economic growth.

The empirical evidence that supports the positive effect of inflation on economic growth rate was found by [28] and [31] which also the same findings were made or supported by [7]. They used co-integrated error correction model to investigate using the data obtained from South Asian countries which include (Bangladesh, Sirlank, India and Pakistan), they came into the conclusion that inflation in the long-run has a positive relationship on economic growth. They made mention that when the inflation rate is on the average is helpful to improve economic growth.

\section{Material and methods}

\subsection{Introduction}

To achieve the aim of this study, this chapter establishes the methods for data analysis for the study. This includes stability test and time series properties of the data that is regression analysis, stationarity test, causality test and lastly, co-integration test.

\subsection{Data Source}

The economic growth rates are calculated from the difference of the log real Gross Domestic Product (real GDP from 1995 to 2019). Likewise, inflation rate is calculated from the difference of the log of Consumer Price Index for the same period. Government expenditure, Foreign Direct Investment (FDI), import and export were included in the model make adjustment and better prediction on the dependent variable. The data used in this study is purer a secondary data obtain from World Bank open data source www.data.worldbank.org of Ghana's inflation, real Gross Domestic Product (GDP) growth rate Government expenditure, Foreign Direct Investment (FDI), import and export. The study adopt Econometric Views (Eviews) software was used for the analyses. The software is chosen because of its user-friendly nature in time series analysis. 


\subsection{Theoretical Frame Work.}

The econometric methods used in this analysis is outlined in this section. The study used a model adopted by [6] which studied the impact of inflation on economic growth in Tanzania. [6] model was transform in this study to suit the model to examine the effect of inflation on economic growth of Ghana. Similar model was also employed and studied the threshold effect of inflation and economic growth rate by [26]

In other to investigate the effect of inflation on economic growth in Ghana, the [17] co-integrating test was conducted the presence of co-integration equation between the two variables. We first test for unit root for these two variables. Stationarity was determine levels and in first differences. The study applied the Augmented Dickey Fuller (ADF) test for unit root Dickey Fuller (1981).

\subsection{Regression Analysis}

Regression analysis was applied to study effect of inflation on economic growth. Following [25] outline elasticity using linear regression model outlined below.

$\operatorname{Ln}(\mathrm{Y})=\Phi+\Phi \ln (\mathrm{X})+\mu t \ldots \ldots \ldots \ldots . . . \mathrm{equation}(1)$ as elasticity

The coefficient $\Phi \mathrm{i}$ is the elasticity. [25] stated that a basic regression with logs, (Y) tends to change by $\Phi$ i unit change in (X). Further, in a linear regression which has both logged variables the dependent variable tends to change by $\Phi \mathrm{i}$ percentage change in the independent variables (X). It means that the regression model or the equation with logged variables are often explain as elasticity. When we then transform the equation (2) below into logarithm form to fit our model, it becomes;

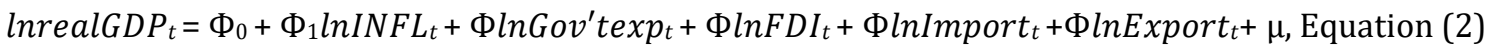

Where the elasticity is $\Phi_{i}=$ coefficient, Real GDP= Real Gross Domestic Product,

Infl = Inflation, Gov'texp = Government Expenditure, Import, Export and $\mu_{t}=$ error term and time period. The above equation will measure the degree of responsiveness of change in GDP growth to changes in the general price levels of goods and services.

\subsection{Unit Root Test}

The aim of conducting stationarity test is to check whether the variables are stationary at levels or at first difference to avoid conducting a spurious regression which cannot be subjected to empirical analysis, forecasting or making predictions [15]. In fact the results for a spurious regression is basically useless. Before we estimate our regression in equation2 it is necessary to perform unit root test check the stationary level of the series we are work with. I he limitation of unit root test is the observation of the series should have a minimum of 20 observations for stationarity test to be conducted if not the result of that series will not be reliable [21, [22]. The test for unit root this study use the most popular methods for the estimation which are Augmented Dickey-Fuller (ADF) unit root test.

The model is estimated in equation (2) by stating the hypothesis. The null hypothesis there is a unit root or the series are non-stationary and the alternative hypothesis also states that the series has no unit root or they are stationary. The $\mathrm{ADF}$ is estimated using the model below;

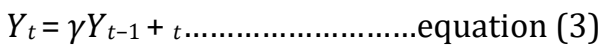

If $\gamma=1$ equation (3) becomes a random walk, that is a non-stationary series. However, Y tends to become stationary if $<$ 1. Also a stationary series can be achieved when variables are not stationary at its level which will require first differencing to achieve stationarity, [32]. The idea of using ADF test for unit root is basically regression Y variable on its own lagged period value $Y_{t-1}$. The equation4 cab further be manipulated as;

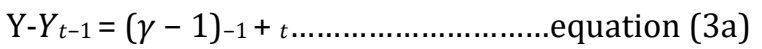

$$
\begin{aligned}
& \Delta Y_{t}=\delta Y_{t-1}+{ }_{t} \ldots \ldots \ldots . . . \text { equation }(3 \mathrm{~b})
\end{aligned}
$$


Where $\delta$ is $(\gamma-1)$ and $\Delta$ is the difference operator. The study estimated equation (3) to test for the null hypothesis $\delta=$ 0 against the alternative hypothesis $\delta \neq 0$. The decision to reject $H o$ is based on the ADF test statistic in absolute terms and 5 percent critical value.

\subsection{Co-Integration Test}

Time series variables are said to be co-integrated if they have a long-run equilibrium, that is if there a relationship between them. If the response variable and the explanatory variables are not stationary but their residuals are stationary it means that those series are said to be co-integrated in the long-run [22]. The study used Johansson test for co-integration to test this series whether they have long run behavior [24]. If the variables are co-integrated it means that they have long term effect and that error must be corrected by estimating the long-run model that is the vector error correction model (VECM) if they are not co-integrated the short-run model is estimated which is the vector autoregressive model (VAR) that is for forecasting, impulse response analysis etc But in this study the study is only interested in estimating their long-run effect on one other to help draw conclusions.

\subsection{Long Run Effect using Fully Modified (FM) Ordinary Least Squares (OLS) Approach}

Co-integration approach are broadly used in empirical macroeconomics and other disciplines. [30] developed the fully modified OLS (FM-OLS) to provide optimal estimates co-integration regression. The approach modifies the OLS regression technique in order to account for serial correlation effects and endogeneity in the explanatory variables that result from the existence of co-integration relationship. The reason for choosing FM-OLS method is because of its property of introducing appropriate correction to overcome inference problem and validate the t-test for long run estimates [23]

To find out the long run effect of inflation on economic growth, the FM-OLS model is specified below;

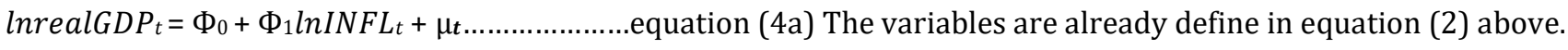

The study also includes other control variables such as Government expenditure (Govtexp), foreign direct investment (FDI), import, and export in to the model to estimate the long run effect. The model is presented below:

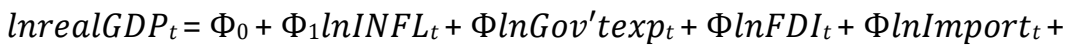

$\Phi \ln \operatorname{Export}_{t}+\mu \ldots \ldots \ldots \ldots \ldots \ldots . . . \mathrm{equation}(4 \mathrm{~b})$

\subsection{Granger Causality Test}

Many econometric model assume different hypothesis to explain variables' association, but they were unable to make sure which variables' cause and effect relationship. [20] defined the lead and lag relations on the part of predictability. He used the VAR model to find out the causal relationship among variables. This test measured two series inflation and economic growth. The study sick to find out whether inflation causes economic growth or economic growth causes inflation in Ghana' economy for study span. The study also find out whether there is autocorrelation and constant variance among the variables in the model.

\subsection{Variables Prior Expectation}

There has been several empirical evidence about the effect of inflation on economic growth around the globe. Where many studies findings proved that inflation is harmful to economic growth and other evidence shows that inflation has a positive impact on economic growth of a country in a given threshold level. However, a strong support can be found on the evidence that inflation is harmful to economic growth in an economy. This could be attributed to different in country's economic policies and different data employed in various analysis.

An empirical evidence by [9] who studied the effect of inflation on economic growth including other two economic variables (interest rate and investment) found out that inflation has a positive impact on Malaysian economy that when inflation increase by 1 percent economic growth goes up by 1.817 percent. According to [25], also found a negative effect of inflation on economic growth of Tanzania economy. That, when inflation goes up by 1 percent GDP decreases by 18.841 percent. A study by [26], used unbalanced panel data which contains 140 countries from a period of 1960 to 1998. They estimated the threshold level of $1 \%$ to $3 \%$ and $11 \%$ to $12 \%$ for developed and developing countries respectively. The study reveals that the threshold for developed countries was lower than the threshold level for developing countries. They also made mention that the inflation rate below the threshold is again to economic growth and inflation rate above were the threshold were negative and significant on economic growth. 


\section{Results and discussion}

\subsection{Introduction}

This chapter presents findings and discussion of the study. The chapter analyzed the effect of inflation rate on economic growth for the period 1995 to 2019. Government Expenditure, Foreign Direct Investment (FDI), Export, and Import variables were conclude in the model to estimate the general fiscal effect on economic growth. The study sought to achieve this objectives; to examine the effect of inflation on economic growth, to establish the relationship between consumer price index (inflation) and real economic growth, to determine the existence of long run relationship and to check for the causal effect among the variables. Model diagnosis were also conducted. Data analyses followed the chronological order of the objectives test stated above starting with unit root testing.

\subsection{Result of Unit Root Test.}

Before testing for co-integration, the study conducted unit root test to test for the order of integration. The study used Augmented Dick-Fuller (ADF) test for unit root; whether the series are stationary at level or at first difference. The results of the test are presented below in table- 1 and 2 below

Table 1 The results of unit root test at levels

Null Hypothesis: Unit root (individual unit root process)

\begin{tabular}{|c|c|c|c|c|}
\hline \multicolumn{3}{|c|}{ Intermediate ADF test results UNTITLED } & \multirow[b]{2}{*}{ Max Lag } & \multirow[b]{2}{*}{ Obs } \\
\hline Series & Prob. & Lag & & \\
\hline LNREALGDP & 0.8972 & 0 & 5 & 25 \\
\hline LNINFL & 0.0736 & 0 & 5 & 25 \\
\hline LNGEXP & 0.8554 & 0 & 5 & 25 \\
\hline LNFDI & 0.5222 & 0 & 5 & 25 \\
\hline LNIMPORT & 0.1857 & 0 & 5 & 25 \\
\hline LNEXPORT & 0.0754 & 0 & 5 & 25 \\
\hline
\end{tabular}

Source: Authors' own Estimation (2021).

Table 2 The results of unit root test at first difference

\begin{tabular}{|c|c|c|c|c|}
\hline \multicolumn{5}{|c|}{ Intermediate ADF test results D(UNTITLED) } \\
\hline Series & Prob. & Lag & Max Lag & Obs \\
\hline D(LNREALGDP) & $0.0041^{* *}$ & 0 & 4 & 24 \\
\hline D(LNINFL) & $0.0003^{* *}$ & 0 & 4 & 24 \\
\hline D(LNGEXP) & $0.0007^{* *}$ & 0 & 4 & 24 \\
\hline D(LNFDI) & $0.0038^{* *}$ & 0 & 4 & 24 \\
\hline D(LNIMPORT) & $0.0001^{* *}$ & 0 & 4 & 23 \\
\hline D(LNEXPORT) & $0.0002^{* *}$ & 0 & 4 & 24 \\
\hline
\end{tabular}

Source: Authors' own Estimation (2021).

In determining the lag length, the Schwarz Information Criterion (SIC) selected the appropriate lag. From the ADF test for unit root output at levels in table-1, indicate that none of the variables were stationary. We fail to reject the null hypothesis of a unit root in table- 1 . Therefor we conclude that, they variables are non-stationary at I(0).They study then took the first difference I(1) for all the variables to test for stationarity. This findings in table-2 conclude that all the variables passes the stationarity test at first difference. Which indicates that the variables are integrated at order one 
$I(0)$. Therefore there is the need to use the Johansen co-integration test to find the linear association among the variables.

\subsection{Result of the Effect of inflation on Economic Growth.}

To estimate the impact of inflation on economic growth, the study used OLS regression analysis method. The linear regression equation as illustrated below in table-3.

Table 3 Results for regression analysis.

\begin{tabular}{|c|c|c|c|c|}
\hline \multicolumn{5}{|c|}{ Dependent Variable: InREALGDP } \\
\hline Variable & Coefficient & Std. Error & t-Statistic & Prob. \\
\hline lnINFL & -0.135233 & 0.071732 & -1.885242 & 0.0740 \\
\hline lnGEXP & 0.777232 & 0.066762 & 11.64186 & 0.0000 \\
\hline lnFDI & 0.224483 & 0.061322 & 3.660750 & 0.0016 \\
\hline lnIMPORT & -0.605396 & 0.235336 & -2.572476 & 0.0182 \\
\hline InEXPORT & 0.166766 & 0.206902 & 0.806016 & 0.4297 \\
\hline C & 8.859906 & 1.968671 & 4.500450 & \\
\hline R-squared & 0.984391 & Mean dependent var & 23.71794 \\
\hline Adjusted R-squared & 0.980488 & S.D. dependent var & 0.969286 \\
\hline S.E. of regression & 0.135394 & Akaike info criterion & -0.962076 \\
\hline Sum squared resid & 0.366633 & Schwarz criterion & -0.671746 \\
\hline Log likelihood & 18.50699 & Hannan-Quinn criter. & -0.878471 \\
\hline F-statistic & 252.2554 & Durbin-Watson stat & 1.450288 \\
\hline Prob(F-statistic) & 0.000000 & & \\
\hline \multicolumn{5}{|c|}{ Source: Authors' own Estimation (2021). } \\
\hline
\end{tabular}

The coefficient of determination $R 2$ is statistically significant that 98.44 percent of variations in economic growth is explained by variations in inflation, Government expenditure, FDI, import and export which means that these variables drives economic growth in Ghana. A 5 percent critical value is used to determine the significance level of the variables.

The results of the regression analysis depicted that inflation has a marginal negative effect on economic growth and is statistically insignificant at $5 \%$ level. This indicate that a 1 percent change in inflation will lead to 0.14 units decline in economic growth, but if the growth rate is declining is not mainly as a results of increase in the general price level of goods and service in the economy but rather other variables, may account for that. This findings justifies expectation in the literature that inflation is harmful to economic growth. The study conclude that, the inflation rate of Ghana, since the start of democratic rule in 1992 overall have a negative effect, but does not have a significant decline on growth.

Moreover, government expenditure has a positive and a statistical significant effect on economic growth of Ghana at 5 percent level. When government expenditure goes up by 1 percent, economic growth will increase by 0.78 units. This imply that government expenditure has a strong positive impact on growth of Ghana's economy. This findings agreed with Wagner's law and Keynesian school of taught that, government spending is as a result of economic growth. Furthermore, FDI has a positive statistically significant effect on economic growth at 5 percent level. When FDI increase by 1 percent, economic growth will increase by 0.22 units. This imply that, the increasing trend in FDI also increase GDP of Ghana. Imports of goods and services shows a negative statistical significant effect at 5 percent level. This indicates that, a 1 percent increase in import decreases economic growth by 0.61 percent. In addition this is also accordance with Keynesian theory of equation $\mathrm{Y}=\mathrm{C}+\mathrm{I}+\mathrm{G}+(\mathrm{E}-\mathrm{M})$. Lastly, exports of goods and services indicates a positive impact at 5 percent level, but was not statistically significant. This indicates that, a 1 percent increase in export increases economic growth by 0.17 units. Exports and imports as a proxy to trade, it means that Ghana has a deficit or negative trade balance. The results also agreed with the Keynesian equation illustrated above. The economy production capacity is not sufficient 
to produce for exports to improve economic growth rate. The study concludes that, export and import as a proxy to trade in has negative effect on economic of Ghana.

\subsection{Results for Co-Integration Test (Johansen Approach).}

Having explained in the previous section, the study proceeds with Johnson co-integration test having found out that all the series are stationary at I(1). The panel-1 below present the results of the trace statistic to determine the number of co-integrating equation for this specification whiles panel-2 present the results of the maximum Eigen-value test which also determine and confirms the number of co-integration questions.

Null hypothesis no co-integration equation.

Table 4 Johansen Co-Integrated test Output

Panel 1 Lags interval (in first differences): 1 to 1

\begin{tabular}{|c|c|c|c|c|}
\hline \multicolumn{7}{|c|}{ Unrestricted Co-integration Rank Test (Trace) } \\
\hline $\begin{array}{c}\text { Hypothesized } \\
\text { No. of CE(s) }\end{array}$ & Eigenvalue & Trace Statistic & $\begin{array}{c}\mathbf{0 . 0 5} \\
\text { Critical Value }\end{array}$ & Prob.** $^{* * \mid}$ \\
\hline None $^{*}$ & 0.929926 & 163.7887 & 95.75366 & 0.0000 \\
\hline At most 1 & 0.831669 & 99.99169 & 69.81889 & 0.0000 \\
\hline At most 2 & 0.735826 & 57.22796 & 47.85613 & 0.0052 \\
\hline At most 3 & 0.510663 & 25.28047 & 29.79707 & 0.1517 \\
\hline At most 4 & 0.187761 & 8.127574 & 15.49471 & 0.4519 \\
\hline At most 5 & 0.122509 & 3.136528 & 3.841466 & 0 \\
\hline
\end{tabular}

Panel 2 Unrestricted Co-integration Rank Test (Maximum Eigenvalue)

\begin{tabular}{|c|c|c|c|c|}
\hline $\begin{array}{c}\text { Hypothesized } \\
\text { No. of CE(s) }\end{array}$ & Eigenvalue & Max-Eigen Statistic & 0.05 Critical Value & Prob.** $^{* * 1}$ \\
\hline None $^{*}$ & 0.929926 & 63.797 & 40.07757 & 0.0000 \\
\hline At most 1 & 0.831669 & 42.7637 & 33.87687 & 0.0034 \\
\hline At most 2 & 0.735826 & 31.9475 & 27.58434 & 0.0129 \\
\hline At most 3 & 0.510663 & 17.1529 & 21.13162 & 0.1649 \\
\hline At most 4 & 0.187761 & 4.99105 & 14.2646 & 0.743 \\
\hline At most 5 & 0.122509 & 3.13653 & 3.841466 & 0 \\
\hline
\end{tabular}

Max-eigenvalue test indicates 3 co-integrating eqn(s) at the 0.05 level: ${ }^{*}$ denotes rejection of the hypothesis at the 0.05 leve: ${ }^{* *}$ MacKinnon-HaugMichelis (1999) p-values: Source: Authors' own Estimation (2021).

In panel 1 , the null hypothesis of co-integration equation indicates 3 co-integration vectors at 0.05 significance level. Therefore, the null hypothesis of no co-integration is rejected indicating that there are 3 co-integrating vectors in the model. The trace statistic value for the co-integration equations with $\left(^{*}\right)$ is greater than the 5 percent critical value with p-value less than 0.05 . This result shows that, co-integrating relationship exist among the variables i.e economic growth and inflation are co-integrated. In panel 2, the results show that Maximum Eigen value test confirms the trace statistic of 3 co-integrating vectors.

\subsection{The Long Run Co-integration Relationship Using Fully Modified Ordinary Least Squares.}

The results of the co-integration method indicates the presence of long run relationship, the Fully Modified Least Squares (FM-OLS) was used to determine the effect of inflation on real economic growth in the long run. The lag length 
for the estimation was obtained using the VAR lag Order Selection Criterion. The coefficients of the estimates are long run elasticity's.

Table 5 Effect of inflation on economic growth.

\begin{tabular}{|c|c|c|c|c|}
\hline \multicolumn{4}{|c|}{$\begin{array}{c}\text { Dependent Variable: InREALGDP } \\
\text { Method: Fully Modified Least Squares (FMOLS) }\end{array}$} & \multirow[b]{2}{*}{ Prob. } \\
\hline Variable & Coefficient & Std. Error & t-Statistic & \\
\hline $\operatorname{lnINFL}$ & -0.155016 & 0.076120 & -2.036455 & 0.0559 \\
\hline $\operatorname{lnGEXP}$ & 0.769856 & 0.067206 & 11.45514 & 0.0000 \\
\hline $\operatorname{lnFDI}$ & 0.215303 & 0.061619 & 3.494107 & 0.0024 \\
\hline InIMPORT & -0.607165 & 0.251886 & -2.410473 & 0.0262 \\
\hline $\operatorname{lnEXPORT}$ & 0.181004 & 0.207142 & 0.873816 & 0.3931 \\
\hline $\mathrm{C}$ & 9.051335 & 2.029003 & 4.460976 & 0.0003 \\
\hline R-squared & 0.984284 & \multicolumn{2}{|c|}{ Mean dependent var } & 23.76307 \\
\hline Adjusted R-squared & 0.980148 & \multicolumn{2}{|c|}{ S.D. dependent var } & 0.960990 \\
\hline S.E. of regression & 0.135400 & \multicolumn{2}{|c|}{ Sum squared resid } & 0.348328 \\
\hline Long-run variance & 0.018327 & & & \\
\hline
\end{tabular}

The coefficient of the long run estimates indicate that inflation rate have a negative relationship to economic growth which was marginally significant at 10 percent but failed the 5 percent statistical significance level. An increase in the rate of inflation by 1 percent will lead to a decrease in real GDP growth by 0.16 units. This findings confirms the theoretical expectation that inflation is harmful to economic growth. In Ghana, changes in economic growth, inflation rate causes less harm considering the coefficient and its significance level. There are other main disturbing factors that causes real GDP to decline. This results is in line with a study by [10] and [33] Ghana, which found out a statistical significant effect at 5 percent level that inflation is harmful to economic growth. That on average 1 percent increase in inflation rate will decrease growth by 0.98 percent in the long run, Ahiakpor stated. But in this study, inflation rate did not pass the statistical significance level at 5 percent this can be attributed to variations in the data span and different time variables included in the model.

Moreover, government expenditure has a positive and a statistical significant effect on economic growth of Ghana at 5 percent level. When government expenditure goes up by 1 percent, economic growth will increase by 0.78 units. This imply that government expenditure has a strong positive impact on growth of Ghana's economy. This findings agreed with Wagner's law and Keynesian school of taught that, government spending is as a result of economic growth. Furthermore, FDI has a positive statistically significant effect on economic growth at 5 percent level. When FDI increase by 1 percent, economic growth will increase by 0.22 units. This imply that, the increasing trend in FDI also increase GDP of Ghana. Imports of goods and services shows a negative statistical significant effect at 5 percent level. This indicates that, a 1 percent increase in import decreases economic growth by 0.61 units. Lastly, exports of goods and services indicates a positive impact at 5 percent level, but was not statistically significant. This indicates that, a 1 percent increase in export increases economic growth by 0.17 units. Exports and imports as a proxy to trade, it means that Ghana has a deficit or negative trade balance. The results also agreed with the Keynesian equation illustrated above. The economy production capacity is not sufficient to produce for exports to improve economic growth rate. The study concludes that, export and import as a proxy to trade in has negative effect on economic of Ghana.

\subsection{Granger Causality Test.}

The study applied Granger causality test to check for causal effect of real GDP growth and inflation. The results of the test is presented below. 
Table 6 VAR Granger Causality/ Block Erogeneity Wald test

\begin{tabular}{|c|c|c|c|}
\hline \multicolumn{4}{|c|}{ Dependent variable: InREALGDP } \\
\hline Excluded & Chi-sq & df & Prob. \\
\hline $\operatorname{lnINFL}$ & 1.250424 & 2 & 0.5351 \\
\hline $\operatorname{lnGEXP}$ & 8.715511 & 2 & 0.0128 \\
\hline $\operatorname{lnFDI}$ & 12.87143 & 2 & 0.0016 \\
\hline $\operatorname{lnIMPORT}$ & 21.57379 & 2 & 0.0000 \\
\hline $\operatorname{lnEXPORT}$ & 13.63156 & 2 & 0.0011 \\
\hline All & 40.22820 & 10 & 0.0000 \\
\hline \multicolumn{4}{|c|}{ Dependent variable: InINFL } \\
\hline Excluded & Chi-sq & $\mathrm{df}$ & Prob. \\
\hline lnREALGDP & 1.982666 & 2 & 0.3711 \\
\hline lnGEXP & 0.947689 & 2 & 0.6226 \\
\hline $\operatorname{lnFDI}$ & 0.952488 & 2 & 0.6211 \\
\hline $\operatorname{lnIMPORT}$ & 0.705450 & 2 & 0.7028 \\
\hline lnEXPORT & 0.949304 & 2 & 0.6221 \\
\hline All & 9.155428 & 10 & 0.5174 \\
\hline
\end{tabular}

The null hypothesis states that there is no causal effect in the explanatory variables when the p-value is $<0.05$ percent against the alternative hypothesis that, there exist a causal effect in the explanatory variables to the outcome variable when the p-value is $>0.05$ percent. When the null hypothesis is failed to be rejected it means that there is no causal effect. Causal effect of Inflation on Economic growth: From the Granger causality output above the null hypothesis for the explanatory variable inflation are rejected the $\mathrm{p}$-value is $>0.05$ percent critical level that the lagged coefficients are not equal to zero (0). Implying that the probability value for inflation is $(0.37)$ percent which is $>0.05$ percent. This indicate that inflation does not Granger-Cause economic growth. This confirms the regression results which shown nonsignificance of inflation on economic growth.

Causal effect Economic growth on Inflation: The coefficients for economic growth variable is not significant at 0.05 percent level this also depicts that real GDP has no causal effect on inflation. The null hypothesis that, economic growth does not Granger-Cause inflation failed to be rejected. Which implies that, economic growth actually does not Granger cause inflation.

Table 7 Model Diagnoses and Goodness of fit tests

\begin{tabular}{|l|l|l|l|}
\hline \multicolumn{2}{|l|}{ Breusch-Godfrey Serial Correlation LM Test } & 0.2792 \\
\hline F-statistic & 1.240877 & Prob. F(1,19) & 0.2068 \\
\hline Obs*R-squared & 1.593943 & Prob. Chi-Square(1) & 0.7988 \\
\hline Heteroskedasticity Test: Breusch-Pagan-Godfrey & Prob. F(5,20) & 0.7463 \\
\hline F-statistic & 0.463334 & Prob. Chi-Square(5) & 0.8952 \\
\hline Obs*R-squared & 2.699031 & Prob. Chi-Square(5) & \\
\hline Scaled explained SS & 1.649474 & & \\
\hline
\end{tabular}




\section{Multicollinearity test}

\begin{tabular}{|c|c|c|c|}
\hline Variance Inflation Factors & $\begin{array}{c}\text { Coefficient } \\
\text { Variance }\end{array}$ & $\begin{array}{c}\text { Uncentered } \\
\text { VIF }\end{array}$ & $\begin{array}{c}\text { Centered } \\
\text { VIF }\end{array}$ \\
\hline Variable & 0.005146 & 56.35579 & 2.173216 \\
\hline LNGEFL & 0.004457 & 2909.566 & 5.076916 \\
\hline LNFDI & 0.003760 & 11.58983 & 2.636512 \\
\hline LNIMPORT & 0.055383 & 1145.525 & 3.307477 \\
\hline LNEXPORT & 0.042808 & 747.6394 & 2.134016 \\
\hline C & 3.875666 & 5496.910 & NA \\
\hline
\end{tabular}

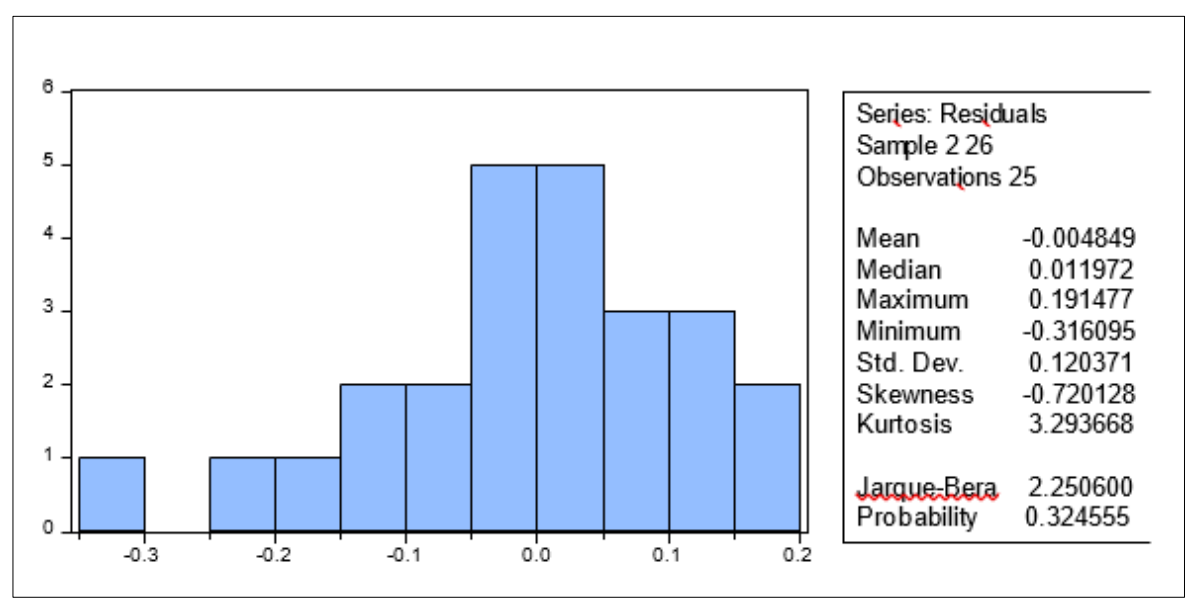

Figure 1 Normality test

\section{Conclusion}

This study examine the impact of inflation on economic growth in Ghana using data from World Bank world development indicators 2019. The empirical results from the study reveals that, inflation has a negative insignificant impact on economic growth in Ghana. This findings is also in line with theoretical expectations and consistent with other findings in the literature including [25];[16]; and [1]. Inflation was found to have a negative impact on economic growth Ghana in the long run. This findings was also in line with theoretical expectations that, inflation is harmful to economic in the long run. [13] also found a negative significant impact of inflation on economic growth in the long term and inflation does not have causal effect on economic growth or vice versa.

\section{Recommendation}

In order to boost economic growth in Ghana, the study recommend that inflation targeting be the best monetary policy measures to grow the economy by maintaining the rate to be within $8+/-2 \%$. There is the need for the government to increase its expenditure, human capital investment, encourage private sector investment by lowering the lending rate, create an enabling environment for foreign direct investment, and improve on exports of goods and services to maintain efficient exchange rate. 


\section{Compliance with ethical standards}

\section{Acknowledgments}

I would like to express my sincere gratitude to Mr. Bofa Adusei, lecturer at the Department of Economics and statistics, Garden City University College, Ghana for his enthusiastic encouragement and useful critiques of this research work.

\section{Disclosure of conflict of interest}

The Authors wish to declare that none has any interest to disclose.

\section{References}

[1] Ahiakpor F, Akapare IA. (n.d.). Short-Run and Long-Run Inflation and Economic Growth Nexus in Ghana. 11(2): $32-49$.

[2] Aziz A, Saymeh F, Sabha SA. Assessment of Small Enterprise Financing, Case of Jordan AssessmentofSmallEnterpriseFinancingCaseofjordan. October 2018.

[3] Dynan K, Sheiner L. GDP as a Measure of Economic Well-being. Hutchins Center on Fiscal \& Monetary Pol Icy At Brookings. 2018; 43: 1-53.

[4] Eggoh JC, Khan M. On the nonlinear relationship between inflation and economic growth. Research in Economics. 2014; 68(2): 133-143.

[5] Erbaykal E, Okuyan HA. Does Inflation Depress Economic Growth? Evidence from Turkey. International Journal of Finance End Economics. 2008; 13(17): 40-47.

[6] Kasidi F, Kenani M. Impact Of Inflation On Economic Growth : A Case Study Of Tanzania. 2017; 3(4): 363-380.

[7] Mallik G, Chowdhury A, Wai T. INFLATION AND ECONOMIC GROWTH : EVIDENCE FROM FOUR SOUTH ASIAN COUNTRIES. 2001; 8(1): 123-135.

[8] Munir Q. Non-Linearity between Inflation Rate and GDP Growth in Malaysia Volume 29, Issue 3 Non-Linearity between Inflation Rate and GDP Growth in Malaysia. 2009.

[9] Naseri M. Effect of Inflation on Economic Growth ; Evidence from Malaysia Effect of Inflation on Economic Growth Evidence from Malaysia Marjan Naseri. 2018.

[10] Sattarov K, Thesis M. Inflation and Economic Growth 2011.

[11] Anaman KA. Determinants of Economic Growth in Brunei Darussalam. Journal of Asian Economics. 2004; 15(4): 777-796.

[12] Barro R. 'Inflation and economic growth': NBER Working Paper. 1995; 53(26): 166-176.

[13] Bittencourt Manoel. Inflation and economic growth in Latin America: Some panel time-series evidence. Economic Modelling. 2012; 29(2): 333-340.

[14] Chan K, Tsay R. "Limiting properties of the least squares estimator of a continuous threshold autoregressive", Biometrika. 1998; 45: 413-426.

[15] Datta K, Kumar C. 'Relationship between inflation and economic growth in Malaysia'. International Conference on Economics and Finance Research IPEDR. 2011; 4(2): 415-16.

[16] Domestic QG. Quarterly Gross Domestic Second Quarter 2020 Quarter, Ghana Statistical Service (GSS). 2019: 112.

[17] Engle R, Granger CWJ. "Cointegration and Error Correction: representation, estimation and testing" Econometrica. 1987: 55: 251-276.

[18] Fischer S, "The Role of Macroeconomic Factors in Growth", NBER Working Paper Series. 1993, Working Paper No. 4565.

[19] Fischer S. "Inflation and growth", NBER Working paper Series. 1983, working paper No 1235.

[20] Granger CWJ. Investigating causal relations by econometric models and cross- spectral methods. Econometrica. August 1996; 37(3): 424-438. 
[21] Gujarati N, Porter D. 3rd edn. Basic Econometrics. US: The McGraw-Hill. 2009.

[22] Gujarati N. 4th edn. Basic Econometrics. New York: The McGraw-Hill. 2004.

[23] Hansen BE., "Threshold Effects in Non-Dynamic Panels: Estimation, Testing, and Inference", Journal of Econometrics. 1999; 93: 345-368.

[24] Johansen, S. Statistical Analysis of Cointegration Vectors, Journal of Economic Dynamics and Control. 1988; 12(2/3): 231-254.

[25] Kasidi F. Estimation of Impact and Elasticity of Foreign Direct Investment on Economic Growth': A Case of Indian Economy. South Asian Business Review. 2010; 2(2): 37-38.

[26] Khan MS, AS Senhadji. "Threshold Effects in the Relationship between Inflation and Growth", IMF Staff Papers. $2011 ; 48(1): 1-21$.

[27] Motley, B. "Growth and Inflation: A Cross-Country Study". Federal Reserve Bank of San Francisco, Working Paper. 1994; 94-08.

[28] Mundell R. "Inflation and Real Interest", the Journal of Political Economy. 1963; 71(3): 280-283.

[29] Mubarik YA. "Inflation and Growth: An Estimate of the Threshold Level of Inflation in Pakistan", State Bank of Pakistan - Research Bulletin. 2005; 1(1-2): 35-44.

[30] Phillips P, B Hansen. "Statistical Inference in Instrumental Variables Regression with I (1) Processes," Review of Economic Studies. 1990; 57: 99-125.

[31] Tobin J. "Money and Economic Growth", Econometrica. 1965; 33: 671-684.

[32] Wei, S. $2^{\text {nd }}$ edition. Time series Analysis: Univariate and Multivariate methods. Boston Pearson. 2006.

[33] Gyamfi, Benjamin. Development assistance and Ghana's long term growth.2019; 10.13140/RG.2.2.33327.56485. 